Святлана Тарасава

Гродна

\title{
Сакралізацыя вобразу Радзімы ў творчасці беларускіх пісьменнікаў Польшчы
}

Сучасная рэчаіснасць практычна не пакінула чалавеку такіх бакоў быцця, што заставаліся б асвечанымі сакральным сэнсам. Разнастайныя навуковыя адкрыцці сёння могуць развянчаць практычна любую трансцэндэнтальную з'яву. I, здавалася б, атэістычнае XX стагоддзе павінна было цалкам дэсакралізаваць чалавечае існаванне.

У той жа час шмат іншых фактараў сведчаць: у чалавеку не толькі не знікла вера $\ddot{y}$ існаванне нейкіх вышэйшых сіл, але і захавалася ўнутраная патрэба напоўніць новым сакральным сэнсам свае асобныя ўспрыняцці, думкі, успаміны і неаддзельныя ад іх аб'екты і падзеі.

Сакралізачыл - (ад лач. sakralis - свяшчэннь), наданне прадметам, з'явам, людзям свяшчэннага, рэлігійнага зместу, падпарадкаванне сачылльных інстылтутаў, культуры $і$ бытавых зносін рэлігійнаму ўлльву. У аснове сакралізачьі - вера ў існаванне свяшчэннага (сакральнага), прочілеглага свецкаму ${ }^{1}$.

Сакральнасцю чалавек можа надзяляць прадметы наваколля, людзей, некаторую прастору. Пры гэтым у чалавечым успрыманні названыя аб'екты набываюць каштоўнасць самай высокай вартасці. Яны валодаюць невытлумачальнай таямнічай сілаю i, адпаведна, патрабуюць ад асобы своеасаблівых павышана-эмацыйных адносін.

Па сцвярджэнні навукоўцаў, у сакральнай геаграфіі адным з аснойных палажэнняй з'яўляецца гіпотэза аб існаванні так званых сакральных цэнтрай, дзе пастаянна адбываецца нейкае свяшчэннадзейства,

1 Беларуская эниыклапедыя: У 18 т.: Рэле - Слаявіна / Рэдкал.: Г. П. Пашкой і інш., Мінск 2002, т. 14, с. 89. 
якое і надае гэтаму месцу асобы сэнс і вылучае яго з іншай прасторы. У чалавека ёсць зайсёдная патрэба захойваць з ім непасрэдную сувязь для абнаўлення і падтрымання жыццёвай сілы. Такой уласцівасцю валодаюць агульнавядомыя і прызнаныя "святыя" мясціны, якіх дастаткова на карце сусвету. Але ёсць месцы, што прызнаюцца ўнікальнымі не для многіх і уесякіх, а толькі тых, хто звязаны з імі сваімі асобымі сувязямі і адносінамі.

У многіх народаў назіраецца традыцыя надзяляць выключнымі якасцямі тое, што складае такое шматзначнае і шматпланавае паняцце, як Радзіма.

Вобраз Радзімы ў творчасці беларускіх пісьменнікаў Польшчы, членаў літаратурнага аб'яднання "Белавежа", з'яўляецца ад пачатку вобразам знакавым, прыцягальным, калі не сказаць адным з самых запатрабаваных і шматзначных. Гэта тэма неаднаразова станавілася аб’ектам літаратуразнаўчага даследавання. Як правіла, у творах беларускіх аўтараў з Польшчы вылучаўся той канкрэтны рэальны свет, які быў напойнены пазнавальнымі дэталямі, запамінальнымі рэчамі. У розных пісьменнікаў канстатавалася нават адносная блізкасць і тоеснасць у выяўленні роднага і дарагога сэрцу месца. Характэрна, што самі паэты заўсёды ўжьвающь слова "Айчьлна", тьлм самылм як бь індывідуалізуючь дадзенае панячче, пазбаўляючь яго ад гучнай $i$ зашмальцаванай пафаснасиі. Айчьна, Бацькаўшчына - гэта той куток Падляшиа, дзе вырас кожны паэт.Увесь час прычягненне да родных мясиін адчувае лірьчны герой паэзіі Яна Чьквіна, Алеся Барскага, Віктара Шведа, Надзеі Aртымовіч $і$ інш. ${ }^{2}$

Сказанае дакладна фіксуе сваё асобае выяўленне вобразу Радзімы ў творчасці гэтых пісьменнікаў. Яна сапраўды практычна заўсёды выступае не як Радзіма-дзяржава, а як канкрэтнае лакальнае месца, з якім чалавек пажыццёва непарыўна звязаны.

Многае з асабіста перажытага беларускімі творцамі стала той першапрычынай, якая абумовіла уззнікненне сакральных адзнак, якімі характарызуецца радзінны свет. 3 другога боку, у творчасці беларускіх пісьменнікай XIX стагоддзя даследчыкамі ўжо адзначана традыцыя выяўлення Радзімы як полюса сакральнасиі $i^{3}$ Усё гэта разам узятае

2 А. Раманчук, Паэзія "Белавежы": сінтэз начьянальнага $і$ агульначалавечага, (у:) Актуальныля праблемь выкладання мовы $i$ літаратуры ў сярэдняй $i$ вышэйшай школе: Матэрыялы рэспубліканскай навуковай канферэнцыі, Гродна 2004, с. 242.

3 С. Даніленка, Беларускі этнічны Космас у творчасиі Я. Чачота, Я. Баричэўскага $і$ В. Дуніна-Мариінкевіча, "Весці АН Беларусі", Серыя гуманітарных навук 1997, № 1, c. 69. 
дазволіла яшчэ глыбей асэнсаваць родную прастору як рэальнасць, што з'яўляецца вытокам іншых сакральных сэнсаў.

У беларускіх пісьменнікаў Польшчы Радзіма выступае сакральным месцам, у якім замацавана свая канкрэтная мадэль існавання, якая вызначае спецыфіку сувязей чалавека з Сусветам. Роднае месца часта ўзносіцца да пэўнага ідэалу, які з'яўляецца неабвержным на працягу ўсяго існавання чалавека. Гэта частка прасторы пачынае набываць у свядомасці чалавека не толькі адзнакі ідэальнага свету (Божага царства), але часам і ўспрымацца як увасабленне Раю.

I таму абсалютна натуральна тое, што практычна ва ўсіх творцаў Радзіма выступае як ідэальная прастора, у якой чалавек жыве ў гармоніi з самім сабой, з прыродай і з творчасцю:

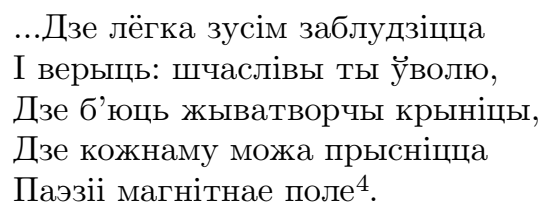

Я. Чыквін, Я жыць хачу, як вы жылі...

Успрыняўшы з маленства родныя мясціны як трывалы і дасканалы свет, паэты не губляюць гэтага адчування і пазней, калі ўжо пабачаць іншае, сутыкнуцца з праявамі новага. Радзіма для беларускіх паэтаў нязменна застаецца прасторай для светлых і ўзвышаных пачуццяй, а самае важнае: толькі тут чалавек здольны адчуць сябе вольным, акрыленым, ачышчаным ад усяго наноснага і другараднага:

Калышашся ў напевах песні роднай,

I мыеш твар у промнях залацістых,

I толькі тут я поўнасцю свабодны,

I толькі тут душой заўсёды чысты ${ }^{5}$.

\section{А. Барскі, Беластоикі край}

Ужыванне паэтам эпітэта "залацісты" відавочна базуецца на даўнім значэнні гэтага колеру: гэта тое, што з'яўляециа вобразам святла, а таму $i$ сімвалізуе святло ${ }^{6}$. I гэтаксама, як і у класічнай літарату-

4 Я. Чыквін, Адно жыциё: выбранае, Беласток 2009, с. 5.

5 Беларускія пісьменнікі Польшчы. Другая палова XX cm. / Укл. Я. Чыквіна, Мінск 2000 , c. 289.

6 А. Марчанка, Колеравая парадыгма ўспрымання $i$ асэнсавання начыянальнай рэчаіснасиі уั творах Якуба Коласа, (у:) Язью и сочиум: Материальл IX Международной научной конференции, 3-4 декабря 2010 г., Минск: В 3 ч., Минск 2011, ч. 3, c. 150 . 
ры, у вершы Алеся Барскага гэтае залатое ззянне ўспрымаециа як адна з праяў зямной $і$ нябеснай прыгажосиі. Сонечны бляск асвятляе краявіды, адухаўляе навакольнь свет, дорыць радасць новага дня $i$, здаеича, натхняе $i$ чалавека на самья светльяя $i$ высокія памкненні ${ }^{7}$.

У Віктара Шведа да такіх самых адчуванняў далучаецца яшчэ пачуццё замілавання і цеплыні ад сустрэчы з блізкімі людзьмі:

Скажу, бывала: еду да бацькоў, I клопаты знікаюць, абавязкі, I адчуваю ўцеху цёплых слой, I мора дабраты, і мора ласкі ${ }^{8}$.

Скажу, бьвала: еду да баџькоў

Вершы Надзеі Артымовіч перадаюць думку пра выключна гаючае узздзеянне на чалавека роднай зямлі, дзе кожны набывае не толькі фізічную сілу і моц, але і лекуецца духоўна:

П’ю прагна

Як цудадзейнае лякарства

Тваё неба мой Бельск (470)

П'ю прагна...

У той жа час вобразу Радзімы-раю ў вершах беларускіх паэтаў процістаіць вобраз антыпод - Горад, які ўвасабляе месца, дзе цалкам парушаны запачаткаваны раней уклад жыцця:

А ӱ веку дваццатым

Спяшаемся мы

3 драўлянае хаты

ў гіганты-дамы (197).

В. Швед, У клетив з бетону

I як вынік гэтаму - адваротнае адчуванне чалавека: пакінутасць, адзінота, зняверанасць: Я не патрэбнь тут нікому // У калаўроче гарадскім.

Той свет, што знаходзіцца за межамі Радзімы-Раю, у тым ліку і Горад, асацыіруецца з Хаосам, месцам, дзе няма ўсталяванага парадку,

7 Тамсама, с. 150.

8 Беларускія пісьменнікі Польшчы. Другая палова XX cm. / Укл. Я. Чыквіна, Мінск, 2000, с. 200. Далей пры спасылцы на гэта выданне ў дужках падаецца старонка. 
дзе пануюць змрок і бязладдзе. Але ў большасці аўтараў выяўляецца думка пра магчымасць вяртання ў Рай, пра духойнае ачышчэнне ад судакраннання з ім.

У выяўленні Радзімы як месца сакральнага натуральна адчуваецца Ўздзеянне своеасаблівага рэлігійнага поля, дзякуючы чаму рэалізуецца думка пра Радзіму як месца для ӱваскрэшання, абнаўлення:

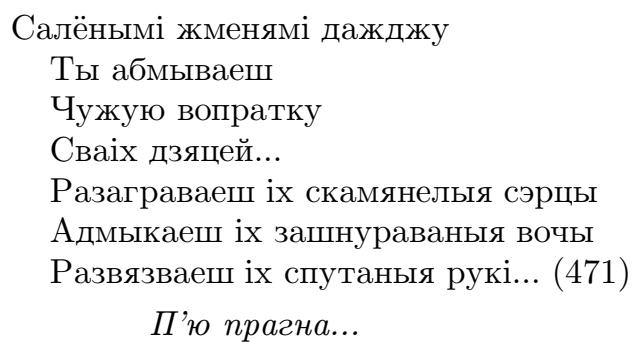

Так, Надзея Артымовіч пераканана сцвярджае: ён, гэты свет, здольны вярнуць чалавеку страчанае, ператварыць слабага ў моцнага, знявераную асобу ў перакананага змагара ці чалавека з моцным духоўным стрыжнем. Праз прыём метафары ў вершы перадаецца аўтарскае адчуванне той магутнай унікальнай сілы, якой валодае родны зямны рай.

Менавіта радзіма робіць чалавека асобай, якая можа па-хрысціянску пакутаваць, прымаць на сябе чужы боль, вучыць дараваць, быць цярпімым, не адчайвацца, не губляць надзеі. Такім матывам прасякнуты вершы Міхася Шаховіча, Юрыя Баены і інш.

Прастора Радзімы становіцца метафізічным ландшафтам, які здольны пераадолець нават саму смерць ( "Мой краю вечньи, краю незаменны" (289)) і перадаць адчуванне вечнасці самому чалавеку (" $\mathrm{Ha}$ роднай Беласточчыне я вечны" (289)).

Творчасць пісьменікаў Польшчы дае магчымасць сказаць, што кожны з аўтараў вызначае дакладную лакалізацыю сакральнага цэнтра, які цесна звязаны з паняццем Радзімы: у Надзеі Артымовіч - гэта Бельск (Бельск - ікона малітва сон жыццё (469)); у Віктара Шведа - вёска Мора (Снішся мне тьл, вёска Мора (200)), а Юрый Баена сцвярджае: Толькі ў Пушиь майчьлм мьл. // У Белавежы нашай, // Святыні нашай!.. (541). У Яна Чыквіна сакральнае месца напачатку адзначаецца дастаткова агульна: На Гайнаўшчьне дыхаециа ўволю9 ${ }^{9}$, паз-

9 Я. Чыквін, Адно жьциё: выбранае, с. 8. 
ней яно канкрэтызуецца адпаведным прызнаннем: Дубічьл, Дубічьл... / ...Як сон залатыл. / ШІтодзённа любячьи, / Я заўжды гатовы / Ваш след иалаваџь, / Які не астый10. Не ў меншай меры дарагім месцам з'яўляецца радзіма і для Алеся Барскага, які канстатуе, што вышэйшае прызначэнне чалавека (...) быць зайсёды пры айчьне // Сваёй блізка. / I паўтараць яе святое // Зайжды імя ${ }^{11}$.

У канкрэтнай геаграфічнай кропцы аўтарамі дакладна адзначаюцца праявы сакральнай прасторы, у якой адбываецца пастаяннае дзейства свяшчэнных сіл. Гэтыя сілы глыбока ўздзейнічаюць на асобу, выклікаючы ў ёй ӱнутраную патрэбу захойваць прамую сувязь з гэтым месцам.

Сімволіка сакральнага цэнтра часта ўвасабляецца ў самых розных прыродных вобразах, часцей тых, якія падказвае нацыянальны ландшафт. У паўднёвых народаў такімі сімваламі часта выступаюць гара, стэп, рака і інш.

Натуральна, што ў беларускай культуры сакральнасцю надзяляюцца свае прыродныя адзнакі: курган, возера, камень. Але асаблівай знакавасцю надзялялі беларусы лес. Лес выхавау характар беларуса,пісаў Уладзімір Караткевіч, - наш лес $i$ чалавек - родныля, $i$ таму беларус любіџь яго ${ }^{12}$. Таму, па сведчанні даследчыка Алеся Бельскага, беларуская паэзія спавядаецча лесу, молічиа яму і ўслаўляе яго ачышчальную сілу13.

Гэта традыцыя прасочваецца і $\ddot{y ~ т в о р ч а с ц і ~ б е л а р у с к і х ~ п і с ь м е н н і к а у ̆ ~}$ Польшчы. Ужо тым жа навукойцам канстатавалася: Даволі характэрны $і$ ў той жа час своеасаблівы паэтычны погляд вылучляе Алесь Барскі ў вершы “О лес...". Гаворачь пра генетычную роднасць з лесам, паэт бачыџь у ім магутнага атланта, які трымае свет. Лес - нібы галоўная апора жычия, прадаўжальнік усяго чалавечага на зямлі ${ }^{14}$ :

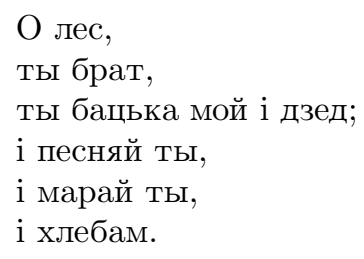

10 Тамсама, с. 12.

11 А. Барскі, Блізкасиь далёкага: паэма, Беласток 1983, с. 74.

12 У. Караткевіч, Зямля пад бельлі крыламі: нарыс, 2-е выд., Мінск 1992, с. 50.

13 А. Бельскі, Свет ад травы да зор: Беларуская паэзія: сістэма вобразаў прыроды, паэтыка пейзажу, Мінск 1998, с. 40.

14 Тамсама, с. 38. 
Ты нада мной, каб не ўпаў на плечы свет, падпёр рукамі неба (291).

Гэты ж аўтар перажывае $\ddot{y}$ лесе яшчэ адно дзіўнае пачуццё: духоўнае ачышчэнне і абнаўленне, вяртанне да існасці і веры ў дабро. 3 лесу, як з храма, ідзём, як анёль, / 3 паднебнага вянчання, / Аддаўшы Богу божае, / А чалавеку уссё людское... (294)

Міхась Шаховіч увогуле самой назвай твора падкрэслівае сакральны характар гэтага прыроднага асяродку. Яго верш называецца "Святы лес". У ім таксама падаецца думка аб ачышчальнай, выратавальнай сіле лесу. А яшчэ праз лес паэт адчувае сувязь з продкамі, для якіх менавіта гэтае месца заўсёды было і прытулкам, і духойным апірышчам. Таму і душа сучаснага чалавека цягнецца да даўняга, сакральнага:

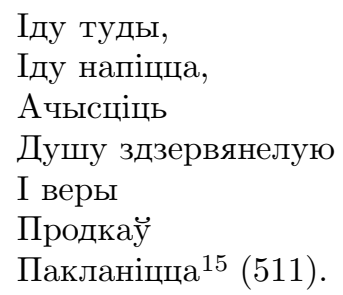

Сакралізаванае ўспрыманне лесу можна знайсці і ў іншых аўтараў. Георгій Валкавыцкі ў вершы "Пад лесам" гаворыць пра лес як пра жывое стварэнне, якое можа даць чалавеку адчуванне абароненасці і заспакаення. Гэтым тлумачыцца прысутнасць у творы матыву вяртання блуднага сына.

А. Бельскі не выпадкова адзначыў у сваім артыкуле, што лес у беларусаў мае некалькі абліччаў, выступае, так бы мовічь, у чатырох аснойных іпастасях: пушча, бор, гай, дуброва ${ }^{16}$. Але незалежна ад назвы адносіны да гэтага прыроднага асяродку ў беларускіх творцаў застаюцца нязменнымі. Уладзімір Гайдук пранікліва разважае пра казачнасць лесу ӱ вершы "У бары", а Юрый Баена самой назвай падкрэслівае выключнасць беларускай пушчы, абазначыўшы яе як "Святыня".

\footnotetext{
15 Тамсама, с. 511.

16 А. Бельскі, Свет ад травы да зор: Беларуская паэзія: сістэма вобразаў прьроды, паэтыка пейзажу, с. 35.
} 
Як бачыцца, выказванне А. Бельскага пра тое, што ў беларускай паэзіі пачучиё лесу - пачучиё гльбока духойнае, нават пантэістычна-сакральнае, інакш кажучы, гэта адчуванне прыроды як святыні, Боскай існасці, высокага хараства ${ }^{17}$ цалкам пацвярджаецца творчасцю беларускіх пісьменнікаў Польшчы.

У культуры многіх народаў здаўна існавала традыцыя надзяляць надзвычайнымі ўласцівасцямі дрэвы. А у старажытных славян цэнтрам свету было прызнана так званае Сусветнае дрэва, якое ўвасабляе з'яднанасць Неба і Зямлі, жыццястойкасць і сілу ўсяго жывога. Гэта і дало штуршок для ўспрымання дрэва як сакральнага аб'екта. Тое ж адзначыў і вядомы еўрапейскі даследчык міфалогіi Мірча Эліяде: $\partial р э в а ~$ становічиа рэлігійным аб'ектам дзякуючь сваёй мочьи, сіле, здольнасиі;...дрэва насычана сакральнасцю, таму што яно мае вертыкальную форму ${ }^{18}$.

У творчасці пісьменнікаў- "белавежцаў” дрэва часта выступае менавіта як сакральны аб'ект, які з'яўляецца неад'емнай часткай роднага навакольнага свету. У гэтай іпастасі выступаюць то клён (А. Барскі, "Прычасці мяне, клёне зялёны..."), то вяз (Я. Чыквін, "Вязе, мой слаўны..."). А М. Шаховіч увогуле адмяжоўваецца ад расліннай канкрэтыкі, чым якраз і набліжаецца да разумення той выключнай сілы дрэва, якую абагаўлялі нашы продкі:
Са страхам і верай
Стаю на каленях,
Б'ю ночы паклоны
Пад падсвечнікам неба,
Малюся да дрэӱ -
Усрыміце маленне,
Адпусціце грахі
Майго дзённага быту,
Што саграшыў
Не сваёю малітвай (499).

Сакральным статусам беларускія пісьменікі надзяляюць не толькі аб'екты і прадметы, звязаныя з родным для іх асяродкам. Не ў меншай меры сакральнасць выяўляецца і $\ddot{y}$ вобразах тых людзей, што насяляюць гэтя прасторы. У абліччы, дзейнасці, ладзе жыцця пісьменікам бачыцца праявы святасці, высокага Боскага пачатку. Алесем Барскім гэты элемент заўважаецца ў звычайнай сялянскай працы:

17 Тамсама, с. 36.

18 М. Элиаде, Трактат по истории религий, СПб 1999, т. I, с. 92. 


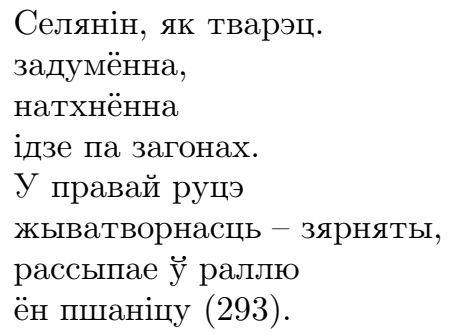

Аўтар нібыта даслоўна паўтарае біблейскае вось, выйшаў сейбіт сеяиь (Ев. ад Мацьвея 13:3). Нават згадка пра пшаніцу ӱ вершы Алеся Барскага не выпадковая. У хрысціянстве каласы пшаніцы - гэта праведнае дабро, Божы дар. У Алеся Барскага, безумоўна, прачытваецца думка аб святасці працы хлебароба, але ж яна дапаўняецца і сцвярджэннем: Хто ведае трывогу сяўбы... / ...той ведае вартасць / хлеба, / песні, / Айчьньь.

Сакральнае напаўненне маюць $\breve{y}$ вершах паэтаў Беласточчыны і жаночыя вобразы. Так, Яну Чыквіну бачацца ў беластоцкім краі незвычайнай прыгажосчі жаночьля твары. Але не толькі зямной вабнасцю прыцягваюць яны: надзеленыя вышэйшай святасцю, яны здольны на надзвычайнае:

Як ад агню, ад іх займаюцца чэрствыя душы I, згарэўшы датла, стаюцца велікадушнымі ${ }^{19}$.

У гэтага ж аўтара ў вершы "Малітва" гучыць кранальная просьба аб магчымасці пазнаць хараство, дабро і праўду, адрасаваная мадонне-славянцы, веліч і красу якой аўтар параўнойвае з іконай Багамаці.

Згаданыя $\ddot{y}$ творах беларускіх аўтараў сакралізаваныя аб'екты выступаюць як транслятары высокіх маральных каштойнасцей, якія здаўна жылі у беларускім народзе, як носьбіты духойнага пачатку і нацыянальных асаблівасцей.

Несумненна, паняцце "радзіма" з'яўляецца вызначальным у светапоглядзе чалавека. Асаблівае напаўненне яно атрымлівае у творчасці беларускіх пісьменікай Польшчы. Для гэтых творцаў Радзіма вызначаецца не толькі канкрэтна-побытавымі праявамі і прыродным ландшафтам, што захавала памяць, яна становіцца сапраўды сакральным месцам, якое з'яўляецца невычэрпнай крыніцай сілы, духоўнай моцы,

19 Я. Чыквін, Адно жыциё: выбранае, с. 105. 
месцам далучэння да святога. У іх мастацкім асэнсаванні вобраз Радзімы набывае адзнакі, адпаведныя паняццю сакральнасці: гэта месца самага высокага ўзройню рэальнасці, непаўторнае, дзівоснае, да канца непазнавальнае i, важна, глыбока шануемае і бязмежна дарагое.

Творчасць пісьменнікаў- “белавежцаў” сведчыць, што духоўнае жыццё сучаснага чалавека, нягледзячы на ўсе дасягненні навуковага прагрэсу, характарызуецца нязменнай патрэбай знаходзіць сакральнае у паўсядзённым быцці.

\title{
S T R E S Z C Z E N I E
}

\section{SAKRALIZACJA OBRAZU OJCZYZNY \\ W TWÓRCZOŚCI PISARZY BIAŁORUSKICH W POLSCE}

W artykule omówiono problem sakralizacji obrazu ojczyzny w twórczości pisarzy białoruskich w Polsce. Obserwacja obiektów sakralnych, które składają się na pojęcie ojczyzny, pozwala sformułować wniosek, że ojczyna jest dla członków Białoruskiego stowarzyszenia „Białowieża” wartością najwyższą, pozostającą w zgodzie z wartościami chrześcijańskimi.

Słowa kluczowe: pisarze białoruscy w Polsce, ojczyzna, sakralizacja, raj, symbolika, las, drzewa, wartości moralne.

\author{
S U M M A Y \\ THE SACRALIZATION OF THE IMAGE OF HOMELAND \\ IN WORKS OF BELARUSIAN WRITERS IN POLAND
}

The article considers the problem of sacralization of the image of homeland in works of Belarusian writers in Poland. In the process of the examination of sacred objects which constitute the notion of homeland, the idea that homeland being their highest value is consistent with basic Christian values has been confirmed.

Key words: Belarusian writers in Poland, homeland, sacralization, paradise, symbolism, forest, trees, moral values. 